\title{
EFFECT OF SHADE TREATMENTS ON MORPHOLOGY, PHOTOSYNTHETIC AND CHLOROPHYLL FLUORESCENCE CHARACTERISTICS OF SOYBEANS (GLYCINE MAX L. MERR.)
}

\author{
KHALID, M. H. B. $.^{1 \dagger}-$ RAZA, M. A. ${ }^{2 \dagger}-$ YU, H. Q. ${ }^{1 \dagger}-$ SUn, F. A. ${ }^{1}-$ ZHANG, Y. Y. ${ }^{1}-$ LU, F. Z. ${ }^{1}$ \\ SI, L. ${ }^{1}-$ IQBAL, N. ${ }^{2}-$ KHAN, I. ${ }^{3}-$ FU, F. L. ${ }^{1}-$ LI, W. C. ${ }^{1 *}$ \\ ${ }^{1}$ Maize Research Institute, Sichuan Agricultural University, Chengdu 611130, PR China \\ ${ }^{2}$ College of Agronomy, Sichuan Agricultural University, Chengdu 611130, PR China \\ ${ }^{3}$ Department of Grassland Science, Sichuan Agricultural University \\ Chengdu 611130, PR China
}

${ }^{t}$ These authors contribute equally to this work.

*Corresponding author

e-mail:aumdyms@sicau.edu.cn; phone: + 86-159-28662654; fax: + 86-028-86290960

address: Sichuan Agricultural University, NO. 211, Huimin Road, Wenjiang District, Chengdu, Sichuan 611130, China

(Received $11^{\text {th }}$ Nov 2018; accepted $16^{\text {th }}$ Jan 2019)

\begin{abstract}
In maize soybean intercropping-system maize plants significantly increase the shade density at soybean canopy, and few people studied the threshold level of shade for sustainable production of soybean in this system. This experiment was started to determine the effect of four different shade treatments $\mathrm{T}_{75}(75 \%) ; \mathrm{T}_{50}(50 \%) ; \mathrm{T}_{25}(25 \%) ; \mathrm{T}_{0}(0 \%$, control) on morphology, physiology and yield of soybean plants. Relative to $\mathrm{T}_{75}$, treatments $\mathrm{T}_{25}$ and $\mathrm{T}_{0}$ significantly increased the stem diameter and stem breaking strength while plant height was decreased. The chlorophyll a, chlorophyll $\mathrm{b}$, and chlorophyll a + $\mathrm{b}$, photosynthetic and chlorophyll fluorescence characteristics were improved as shade decreased, and maximum values were observed in $\mathrm{T}_{25}$ and $\mathrm{T}_{0}$. Similarly, enzymatic activity of Rubisco was accelerated from $\mathrm{T}_{75}$ to $\mathrm{T}_{0}$. However, genes related to sucrose synthesis (SS and SPS) were down-regulated by increasing shade $\left(T_{75}\right)$. Importantly, non-significant differences were measured for seed-yield between $T_{25}$ and $\mathrm{T}_{0}$, and the plants of soybean under $\mathrm{T}_{25}$ produced $88 \%$ of $\mathrm{T}_{0}$ yield. Overall, these results implied that agronomist should develop an appropriate intercropping planting pattern where the maximum shade density ranges from 20 to $30 \%$ to obtain higher seed yield of soybean crop under intercropping-system.

Keywords: Rubisco, intercropping, chlorophyll fluorescence characteristics, sucrose synthesis, seedyield
\end{abstract}

\section{Introduction}

Sun radiations are among the most important abiotic factors for agricultural production (Yang et al., 2014, 2018a). For most crop plants, even a slight increase or decrease in light intensity leads to considerable changes in photosynthetic characteristics (Wu et al., 2017). Light intensity affects the central processes of crops such as physiology, biochemistry and cell division (Kong et al., 2016; Yang et al., 2018b; Wu et al., 2018). Indeed, the numerous plant processes impair with decreasing light intensity which bring dramatic developmental and physiological changes, leading to a rapid decrease of these processes (Yang et al., 2015; Wu et al., 2016). Shading conditions could affect carbon balance of crop plant because the carbohydrate (sugars) demand increases while its production decreases: rates of physiological processes rise while the photosynthetic yield reduces (Yang et al., 2018a). Accordingly, tolerance to 
shade stress reduced at low photosynthetic rate in $\mathrm{C}_{3}$ plants ( $\mathrm{Su}$ et al., 2014). Moreover, the pattern of carbohydrates (Sugars) into expensive processes, like the biosynthesis of defense proteins (notably light-harvesting chlorophyll protein) raises with increasing shade (Yang et al., 2018a). The photosynthetic rate is the major driver of crop plant carbon balance, optimum and continuous availability of light should also be considered into account to study the plant responses to shade stress.

Crop growth as dry matter production is largely dependent on current photosynthesis and, therefore, one of the main important changes by shade stress in crop growth is ascribed to its huge reduction of net photosynthesis (Yang et al., 2018b). Reductions in photosynthesis could occur thanks to two main principle mechanisms (Yang et al., 2017): (i) decrease $\mathrm{CO}_{2}$ diffusion into leaves, since the decrease internal and stomatal conductance ( $g_{i}$ and $g_{s}$, respectively), and (ii) metabolic potential inhibition for photosynthesis by inhibiting the leaf growth and enlargement by controlling the cell proliferation (Wu et al., 2017, 2018). However, further investigations are needed due to the relative significance of such mechanisms is debatable. The amount and activity of important enzymes involved in $\mathrm{CO}_{2}$ fixation and regeneration of rubisco-1, 5bisphosphate (RuBP) determined the metabolic potential of photosynthesis in plants under different conditions (Seemann and Sharkey, 1986; Delfine et al., 1999; RedondoGómez et al., 2007) as well as the activity and content of light capturing components, electron transport fragments, and energy transferring enzymes (Kao et al., 2003; Ranjbarfordoei et al., 2006; Stepien and Klbus, 2006). In photosynthesis Rubisco (RuBP carboxylase or oxygenase) catalyzes the process of $\mathrm{CO}_{2}$ fixation (Mauser et al., 2001), which is directly involved in the first phase of Calvin Benson cycle and accounting for 12 to 35 percent of the leaf protein especially in $\mathrm{C}_{3}$ crop plants (Evans and Seemann, 1989). In past reports, it has been revealed that the main biochemical restraint involved in shade-associated down regulation of net photosynthetic rate was reduction in the amount or activity of Rubisco (Evans and Seemann, 1989).

In past few years, chlorophyll fluorescence measurements have been known as an informative and useful indicator characterizing different light responses of photosynthesis. Considerable attention was paid to investigate and to determine the important characteristics of this technique (Schreiber et al., 1995). Chlorophyll fluorescence mainly and effectively used to measures the quantum yield of photosystem II and photo-inhibition by determining the potential quantum yield under prevailing light and shade conditions (Rascher et al., 2000). Shade significantly affected the performance and structure of the photosynthetic apparatus (Yao et al., 2017). It blocks the energy transport from PSII to PSI, reduces the leaf thickness, palisade and spongy tissues which results in low chlorophyll fluorescence (Wu et al., 2017; Yao et al., 2017). Thus, in this present study we aim to investigate the chlorophyll fluorescence parameters of soybean plants in response to different shading conditions because plant photosynthetic characteristics are directly dependent on the net performance of chlorophyll fluorescence parameters.

Maize (Zea mays L.) soybean (Glycine max L. Merr.) intercropping system is the main planting pattern for cereal and legume production (Rahman et al., 2017). Within the maize-soybean intercropping system - described here as the deliberate sowing of soybean crop within the intercropping strip area of maize planting - the presence of maize crop adds a level of complexity in terms of light environment dynamics for resource-use. Importantly, intercropping system of maize and soybean is used extensively in many parts of China and farmers are achieving a land equivalent ratio of 
1.3-1.4 that is much higher than other relay-intercropping systems in the world (Liu et al., 2018). However, soybean plants are extremely sensitive to shading conditions (Wolff and Coltman, 1990; Feng et al., 2018) and in this system soybean plants suffered from severe maize shading during their vegetative growth period from germination to maturity that increased the seedling height of soybean plants and it became more susceptible to lodging as the intensity of shade increases (Li et al., 2014a,b). Physiomorphological responses of soybean plant under shade conditions have also been considered. A number of studies have shown the significant reduction in stomatal conduction, photosynthetic rate, number of nodes, number of seeds and eventually seed yield (24 50\%) under shade conditions (Yang et al., 2017). Therefore, great emphasis is placed on crop management with an aim to make plants more efficient in light use and enhance yield under shade conditions. However, the comprehensive understanding of physiology, morphology and gene expression related to carbon metabolism (SS and SPS) is still unclear because they are highly influenced by environmental factors under changing conditions especially intercropping systems.

To investigate the role of shading in regulation of soybean morphology and reproductive development, studies of shade treatments on soybean plants were carried out to (i) determine the impact of different shade treatments on morphological characteristics of soybean plants, (ii) study the effect of different shade treatments on photosynthetic and chlorophyll fluorescence parameters of soybean plants, and (iii) to suggest the threshold level of light intensity required by soybean plants for utilizing the available resources adequately to produce higher soybean seed yield under intercropping conditions. Overall, the main objective of this paper is to provide information for agronomists to develop appropriate planting patterns in which soybean plants receive optimum light intensity for their growth.

\section{Materials and Methods}

\section{Plant Material and Growth Condition}

Pot experiment was conducted at the greenhouse characterized by a $12 \mathrm{~h}$ dark/12 $\mathrm{h}$ light photoperiod, $28^{\circ} \mathrm{C}$ day and $25^{\circ} \mathrm{C}$ night temperature and approximately $60 \%$ relative humidity (in 2018). Experiment was complete randomized design with shade tolerant cultivar of soybean (Glycine max L.) Nandou-12 bred by NAAS (Nanchong Academy of Agricultural Sciences) was selected from 30 soybean varieties recognized on the basis of shade tolerance. The ten seeds were sown in pots with dimension of (30 cm diameter, $20 \mathrm{~cm}$ height). Soil was collected from the tillage layer of $0-10 \mathrm{~cm}$ depth at farm land located in Wenjiang, China. Soil textural class is silty clay loam or silty clay. Chemical properties were: $29.0 \mathrm{~g} \mathrm{~kg}^{-1}$ of SOC, $2.10 \mathrm{~g} \mathrm{~kg}^{-1}$ of total $\mathrm{N}$, $0.78 \mathrm{~g} \mathrm{~kg}^{-1}$ of total $\mathrm{P}, 16.0 \mathrm{~g} \mathrm{~kg}^{-1}$ of total $\mathrm{K}, 154 \mathrm{mg} \mathrm{kg}^{-1}$ of available $\mathrm{K}$ and $7.11 \mathrm{of} \mathrm{pH}$ $(1: 5 \mathrm{v} / \mathrm{v})$. The soil was air-dried and sieved through a 4-mm sieve. Basal nutrients were applied at the following rates $\left(\mathrm{mg} \mathrm{kg}^{-1}\right)$ : 210 urea, $215 \mathrm{KH}_{2} \mathrm{PO}_{4}, 160 \mathrm{CaCl}_{2} .2 \mathrm{H}_{2} \mathrm{O}$, $45 \mathrm{MgSO}_{4} .7 \mathrm{H}_{2} \mathrm{O}, 8$ Fe-EDTA, $7 \mathrm{ZnSO}_{4}$ and $4 \mathrm{CuSO}_{4}, 0.8 \mathrm{H}_{3} \mathrm{BO}_{3}$, $6.8 \mathrm{MnSO}_{4} . \mathrm{H}_{2} \mathrm{O}$, $11 \mathrm{ZnSO}_{4} .7 \mathrm{H}_{2} \mathrm{O}, 3 \mathrm{CuSO}_{4} .5 \mathrm{H}_{2} \mathrm{O}, 0.5 \mathrm{CoSO}_{4} .7 \mathrm{H}_{2} \mathrm{O}, 0.4 \mathrm{Na}_{2} \mathrm{MoO}_{4} .2 \mathrm{H}_{2} \mathrm{O}$. All the plantnutrients were mixed thoroughly with sand and soil. After the germination of soybean seeds, three plants per pot were maintained up to maturity and every treatment had 15 pots. In addition, when the first trifoliate leaves developed the soybean seedlings were transferred to four different shade treatments (Shao et al., 2014): $\mathrm{T}_{75}$ (75\% shade); $\mathrm{T}_{50}$ (50\% shade); $\mathrm{T}_{25}$ (25\% shade); $\mathrm{T}_{0}(0 \%$ shade, normal sunlight) and the shaded 
conditions were provided by a covering the pots with black nylon net. The experimental period duration was 110 days. Plants were harvested at maturity and seeds were airdried for seed yield and yield related parameters.

\section{Measurements and Sampling}

\section{Plant Morphological Traits}

Plants were collected from each replicate for morphological measurements, the plant height; stem diameter and plant biomass were measured at stages $\mathrm{V}_{4}$ (four trifoliate of vegetative growth), $R_{1}$ (flower initiation at the start of reproductive growth) and $R_{5}$ (seed filling at the start of seed formation) of soybean because these are the critical stages which determines the growth and development of soybean. All the plant samples of soybean plants were placed to $105^{\circ} \mathrm{C}$ for 1 hour and dried to constant weight at $75^{\circ} \mathrm{C}$ plant biomass. Leaf area was measured by using (CI-203 CID Bio-Science Portable Instruments for Precision Plant Measurement Inc. 1554 NE 3rd Ave, Camas, WA USA). The basal internode (first internode) was used to determine the stem breaking strength of soybean plants by using the digital plant lodging tester (YYD-1, Zhejiang Top Instrument Co. Ltd., Hangzhou, China) according to the previously described method (Liu et al., 2016).

\section{Photosynthetic Pigment Concentration}

Latest fully expanded leaves from each treatment were sampled. Chlorophyll (Chl a, $\mathrm{Chl} \mathrm{b}$, and $\mathrm{Chl} \mathrm{a}+\mathrm{b}$ ) was extracted by grinding samples with chilled mortar and pestle in $10 \mathrm{ml}$ of $80 \%$ acetone and centrifuged $1000 \mathrm{rpm}$ for $3 \mathrm{~min}$ at $4{ }^{\circ} \mathrm{C}$. The samples were placed in ice-cold $10 \mathrm{ml}$ of $80 \%$ aqueous acetone solution in the dark for $24 \mathrm{~h}$ at room temperature. The supernatant was then separated and analyzed by spectrophotometer (UV-2250, Kyoto, Japan) at wavelengths of 663, 645, and $470 \mathrm{~nm}$ as described by Fan et al. (2018) to evaluate the $\mathrm{Chl} \mathrm{a,} \mathrm{Chl} \mathrm{b,} \mathrm{and} \mathrm{Chl} \mathrm{a} \mathrm{+} \mathrm{b} \mathrm{content,} \mathrm{respectively} \mathrm{(Fan} \mathrm{et} \mathrm{al.,}$ 2018).

\section{Photosynthesis}

Three fully expanded leaves of soybean plants from each treatment were selected at $\mathrm{V}_{4}, \quad \mathrm{R}_{1}$ and $\mathrm{R}_{5}$ stages of soybean. Photosynthetic parameters including net photosynthetic rate $\left(P_{\mathrm{n}}\right)$, transpiration rate $\left(T_{\mathrm{r}}\right)$ and intercellular $\mathrm{CO}_{2}$ concentration $\left(C_{\mathrm{i}}\right)$ were measured with the help of portable photosynthesis system (Model LI-6400, LICOR Inc., Lincoln, NE) between 10:00 and 11:00 am. The following settings were used: PARi $=1,000$, stomatal ratio $=0.5$, flow $=500 \mu \mathrm{mol} \mathrm{mol}{ }^{-1}$ and reference $\mathrm{CO}_{2}$ concentration $=400 \mu \mathrm{mol} \mathrm{mol}{ }^{-1}$.

\section{Chlorophyll fluorescence measurements}

Chlorophyll fluorescence measurement was taken by using Fluor Technologia operated using the Fluor Images software. Fully expanded leaf samples from each treatment were taken and immediately preserved in plastic bags and placed in ice box preventing from the direct light. Then by using above mention software, samples were passed to fluorescence analyzing device. We examined maximum quantum yield $(\mathrm{Fv} / \mathrm{Fm})$, effective quantum yield of photosystem ( $\phi \mathrm{PSII})$, photochemical quenching (qP) and electron transport rate (ETR) by placing 20 min under light and dark 
conditions. Previously published method was followed by using FluorImager software, Technologia LTD version 2.2.2.2 (Pan et al., 2017).

\section{Rubisco Analysis}

For the measurements of Rubisco activated enzyme, frozen leaf samples $(1 \mathrm{~g})$ of soybean plants were ground with a mortar and pestle in an ice box and $2 \mathrm{ml}$ of extraction buffer solution was used. The extracted solution was centrifuged $7000 \mathrm{rcf}$ at $4^{\circ} \mathrm{C}$ for $15 \mathrm{~min}$. Double antibody sandwich method was used to determine the level of plant Rubisco activase (RCA). The Rubisco activase (RCA) antibody was encapsulated by the micropore plate to form solid phase antibody, which was added to the micropore of the monoclonal antibody successively. $40 \mu \mathrm{l}$ of sample diluent was added first and then $10 \mathrm{ml}$ of sample solution in the micropore plate. The micropore plate was sealed with a plastic film for incubation at $37^{\circ} \mathrm{C}$ for $30 \mathrm{~min}$ and this incubation was repeated 5 times. Body - antigen - enzyme - labeled antibody complex, after thorough washing and substrate TMB color. TMB is transferred under the catalysis of HRP enzyme. Turn it into blue and turn it into the final yellow color under the action of an acid. After adding the stop solution, the absorbance (OD value) was measured within $15 \mathrm{~min}$ at $450 \mathrm{~nm}$ wavelength by enzyme marker and the sample was calculated by standard curve. The Rubisco activity was expressed as U/g (Seemann, 1989).

\section{Biomass Accumulation and Distribution}

For plant biomass accumulation and partitioning in different soybean plant organs, six soybean plants of two pots, were destructively sampled at $V_{4}, R_{1}$ and $R_{5}$ stages of soybean. Then all the collected soybean plants were separated into root, stem, leaves, and pod, and placed in oven for one hour at $105^{\circ} \mathrm{C}$ to kill the fresh-tissues and then dried the samples at $65^{\circ} \mathrm{C}$ to measure the constant weight before weighing of each plant organ of soybean for total biomass accumulation and partitioning analysis.

\section{Carbon Status and Real-time Quantitative PCR Verification}

To measure the starch and soluble sugar content soybean leaves were collected at $\mathrm{V}_{4}$ stage at the end of the day and analyzed by following the previous method (Cross et al., 2006). Meanwhile, the expanding leaves of soybean plants at $V_{4}$ from all the treatments were collected for the determination of RNA abundance. All the leaves were labeled and frozen in liquid nitrogen immediately. Total RNA was extracted with RNAiso Plus (Takara, Japan). Reverse transcription and amplification of cDNA were performed using SuperScript II First-Strand Synthesis for qRT-PCR (Takara, Japan). Real-time quantitative PCR was conducted in CFX $96^{\mathrm{TM}}$ Real-Time System (Bio-Rad, USA) and $2^{-\triangle \Delta \mathrm{CT}}$ method used for data analysis.

\section{Seed Yield and Yield Parameters}

In the current experiment, all the remaining pots ( 9 pots, 27 plants) were collected from every treatment at maturity. All these collected sampled were utilized to measure the seed yield and yield components. All the sampled plants were dried in sun-light for seven days, threshed by hand and weighed to measure the seed yield of every treatment and then converted into g plant ${ }^{-1}$. The seed number plant ${ }^{-1}$ was counted for all the sampled plants and average seed number plant ${ }^{-1}$ was calculated. Three lots of 100 seeds were collected from bulk seed lot of every treatment and dried in oven at $65^{\circ} \mathrm{C}$ till 
constant weight achieved, and then seed weight (mg) was measured by using an electrical balance and mean weight was calculated.

\section{Statistical Analysis of Data}

All the data recorded for every parameter was analyzed using computer software Statistix (version, 8.1. Statistix, USA) (Raza et al., 2018a). Analysis of variance (ANOVA) technique and least significance difference (LSD) test were employed to assess the effect of shading treatments on measured parameters, and all the means were compared at 5\% probability level. Moreover, Microsoft Excel program was used for the graphical presentation of data using standard error $( \pm \mathrm{SE})$.

\section{Results}

\section{Morphological Characteristics}

Different light treatments considerably changed the morphological characteristics of soybean plants at all growth stages $\left(\mathrm{V}_{4}, \mathrm{R}_{1}\right.$, and $\left.\mathrm{R}_{5}\right)$. Figure 1 shows the morphological characteristics of soybean plants under different light treatments.

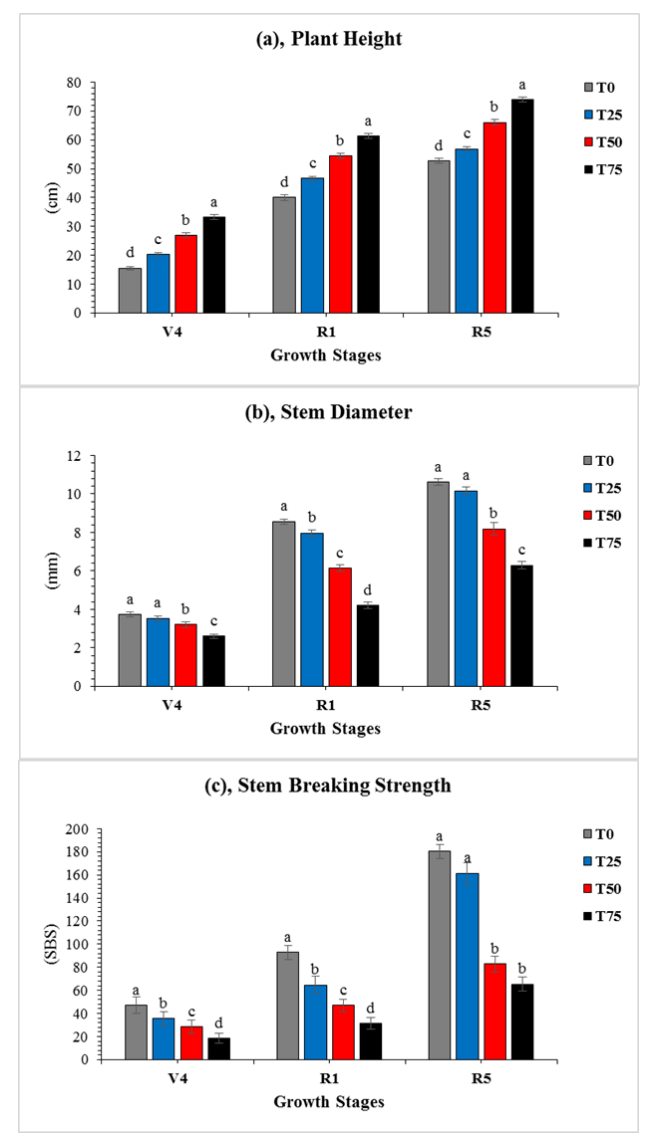

Figure 1. Changes in plant height (a), stem diameter (b), and stem breaking strength (c) of soybean plants as affected by different photosynthetically active radiations treatments at $V_{4}$ (four trifoliate stage), $R_{1}$ (flower initiation stage), and $R_{5}$ (seed formation stage). $T_{75}, T_{50}, T_{25}$, and $T_{0}$ refer to $75 \%, 50 \%, 25 \%$, and $0 \%$ shade, respectively. Means are averaged over three replicates. Bars show \pm standard errors, $(n=3)$. Within a bar, different lowercase letters show a significant difference $(p \leq 0.05)$ between treatments 
In our study, different light treatments had a significant $(\mathrm{P}<0.05)$ impact on plant morphological parameters, the plant height $(\mathrm{PH})$ of soybean plants were substantially increased from $\mathrm{T}_{0}$ to $\mathrm{T}_{75}$ at all growth stages. Specifically, the highest $\mathrm{PH}$ 33.2, 61.3, and $73.9 \mathrm{~cm}$ of soybean plants were recorded under $\mathrm{T}_{75}$, and the lowest $\mathrm{PH}$ 15.6, 40.0, and $52.7 \mathrm{~cm}$ were measured in $\mathrm{T}_{75}$ at $\mathrm{V}_{4}, \mathrm{R}_{1}$, and $\mathrm{R}_{5}$, respectively. Meanwhile, opposite findings were measured for stem diameter (SD) and stem breaking strength (SBS). Compared with $\mathrm{T}_{75}, \mathrm{SD}$ and SBS significantly increased under $\mathrm{T}_{25}$ and $\mathrm{T}_{0}$, and the SD and SBS of $\mathrm{T}_{25}$ and $\mathrm{T}_{0}$, respectively improved by $41 \%$ and $60 \%$, and $38 \%$ and $64 \%$ at $\mathrm{R}_{5}$, than those in $\mathrm{T}_{75}$. Importantly, our findings show that the shade from $25 \%\left(\mathrm{~T}_{25}\right)$ to $0 \%\left(\mathrm{~T}_{0}\right)$ significantly improves the morphology of soybean plants by increasing the SD and SBS.

\section{Chlorophyll Content}

In our experiment, the different light treatments significantly $(\mathrm{P}<0.05)$ affected the chlorophyll ( $\mathrm{Chl} \mathrm{a}, \mathrm{Chl} \mathrm{b}$, and $\mathrm{Chl} \mathrm{a}+\mathrm{b}$ ) content of soybean leaves at all stages. The contents of $\mathrm{Chl} a, \mathrm{Chl} \mathrm{b}$, and $\mathrm{Chl} \mathrm{a}+\mathrm{b}$ of soybean leaves under $\mathrm{T}_{75}, \mathrm{~T}_{50}, \mathrm{~T}_{25}$, and $\mathrm{T}_{0}$ were measured, as presented in Figure 2.

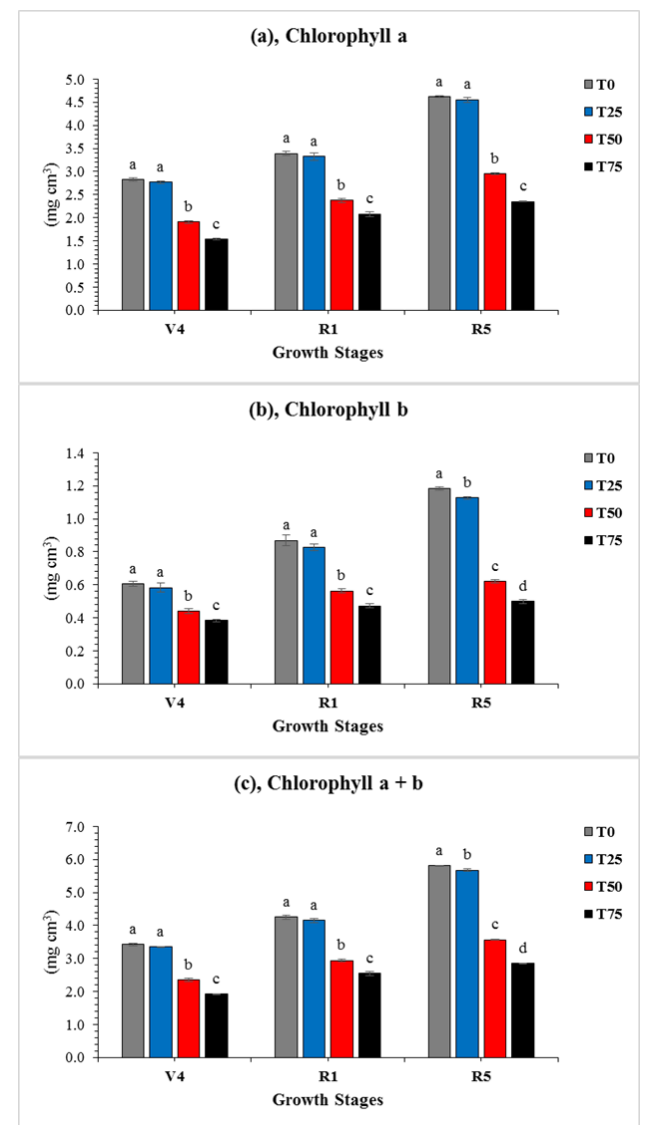

Figure 2. Changes in chlorophyll a (a), chlorophyll $b(b)$, and chlorophyll $a+b(c)$ content of soybean plants as affected by different photosynthetically active radiations treatments at $V_{4}$ (four trifoliate stage), $R_{1}$ (flower initiation stage), and $R_{5}$ (seed formation stage). $T_{75}, T_{50}, T_{25}$, and $T_{0}$ refer to $75 \%, 50 \%, 25 \%$, and $0 \%$ shade, respectively. Bars show \pm standard errors, $(n=$

3). Within a bar, different lowercase letters show a significant difference $(p \leq 0.05)$ between treatments 
We observed that decreasing shade from $\mathrm{T}_{75}$ to $\mathrm{T}_{0}$ increased the $\mathrm{Chl} \mathrm{a}, \mathrm{Chl} \mathrm{b}$, and $\mathrm{Chl}$ $\mathrm{a}+\mathrm{b}$ contents at all measured growth stages. Interestingly, the $\mathrm{Chl} \mathrm{a}, \mathrm{Chl} \mathrm{b}$, and $\mathrm{Chl} \mathrm{a}+\mathrm{b}$ contents of soybean leaves were found non-significant between $\mathrm{T}_{25}$ and $\mathrm{T}_{0}$ treatments,

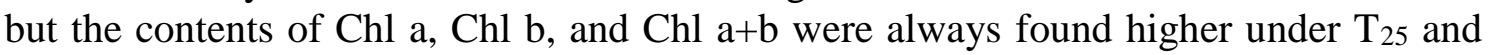
$\mathrm{T}_{0}$ than those of in $\mathrm{T}_{75}$ treatment. Overall, at $\mathrm{R}_{5}$, the $\mathrm{Chl} \mathrm{a}$, Chl b, and $\mathrm{Chl} \mathrm{a}+\mathrm{b}$ contents increased by $48 \%, 56 \%$, and $50 \%$, under $\mathrm{T}_{25}$ in comparison with $\mathrm{T}_{75}$, respectively, suggesting a direct link of chlorophyll contents with the changes in available light intensity.

\section{Photosynthetic and Chlorophyll Fluorescence Characteristics}

Table 1 presents the photosynthetic characteristics of soybean plants in response to different light treatments. Relative to $\mathrm{T}_{75}$ treatment, photosynthetic rate $(\mathrm{Pn})$ and transpiration rate $(\mathrm{Tr})$ enhanced considerably from $\mathrm{T}_{50}$ to $\mathrm{T}_{0}$ treatments, while stomatal conductance $(\mathrm{Gs})$ and intercellular $\mathrm{CO}_{2}$ concentration $(\mathrm{Ci})$ of soybean plants were reduced at all $\mathrm{V}_{4}, \mathrm{R}_{1}$, and $\mathrm{R}_{5}$ (Table 1). The Pn of $\mathrm{T}_{50}, \mathrm{~T}_{25}$, and $\mathrm{T}_{0}$ respectively improved by $12 \%, 31 \%$, and $32 \%$ at $\mathrm{V}_{4}, 11 \%, 27 \%$, and $28 \% \mathrm{R}_{1}$, and $7 \%, 17 \%$, and $22 \%$ at $\mathrm{R}_{5}$ as compared to those under $\mathrm{T}_{75}$. Additionally, all the photosynthetic parameters of soybean plants at $R_{5}$ followed the same pattern to that of $V_{4}$ and $R_{1}$. Importantly, at $V_{4}$ and $R_{1}$ soybean plants exhibited the non-significant differences for photosynthetic characteristics under $\mathrm{T}_{25}$ and $\mathrm{T}_{0}$, suggesting that shade of $25 \%$ to $0 \%$ was enough to maintain the optimum photosynthetic rate for better growth and development.

Table 1. Effect of different photosynthetically active radiations treatments on photosynthetically characteristics and enzymatic activity Rubisco of soybean plants at $V_{4}$ (four trifoliate stage), $R_{I}$ (flower initiation stage), and $R_{5}$ (seed formation stage)

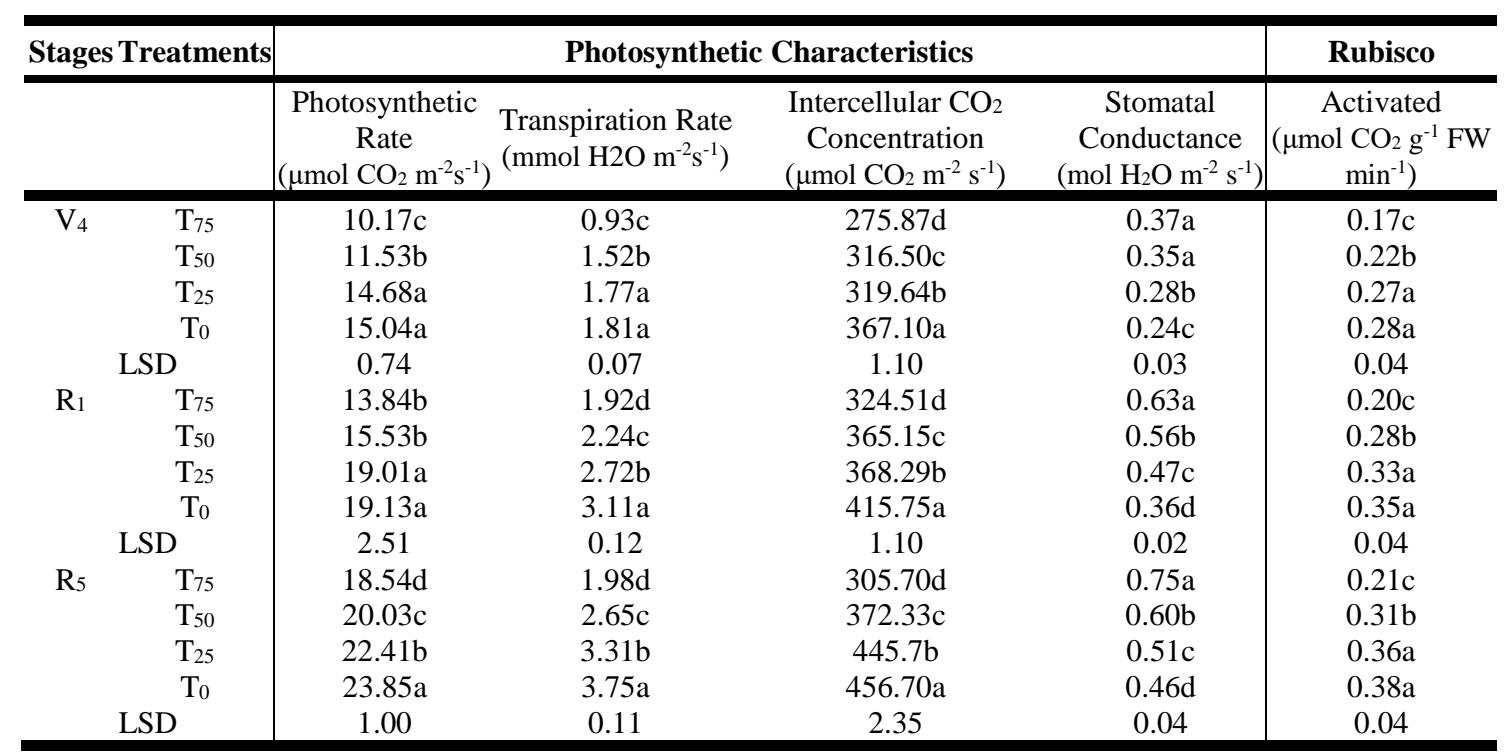

$\mathrm{T}_{75}, \mathrm{~T}_{50}, \mathrm{~T}_{25}$, and $\mathrm{T}_{0}$ refer to $75 \%, 50 \%, 25 \%$, and $0 \%$ shade, respectively

The fate of absorbed solar energy in leaves of soybean at three different growth stages was investigated under changing light conditions, and shows in Table 2. In the present study, the chlorophyll fluorescence parameters including $\mathrm{F}_{\mathrm{v}} / \mathrm{F}_{\mathrm{m}}, \Phi_{\mathrm{PSII}}, \mathrm{qP}$, and ETR were changed significantly under different light treatments. The $\mathrm{F}_{\mathrm{v}} / \mathrm{F}_{\mathrm{m}}, \Phi_{\mathrm{PSII}}, \mathrm{qP}$, 
and ETR of soybean leaves in $\mathrm{T}_{25}$ and $\mathrm{T}_{0}$ were found significantly higher than those under $\mathrm{T}_{75}$. Moreover, treatment $\mathrm{T}_{25}$ and $\mathrm{T}_{0}$, at $\mathrm{R}_{5}$ significantly increased the chlorophyll fluorescence values of $\mathrm{F}_{\mathrm{v}} / \mathrm{F}_{\mathrm{m}}, \Phi_{\mathrm{PSII}}, \mathrm{qP}$, and ETR by $4 \%$ and $5 \%, 17 \%$ and $21 \%, 11 \%$ and $13 \%$, and $17 \%$ and $21 \%$, respectively, as compared to $\mathrm{T}_{75}$ treatment, indicating that adequate light intensity $\left(\mathrm{T}_{25}\right.$ and $\left.\mathrm{T}_{0}\right)$ plays the fundamental role in improving the chlorophyll fluorescence parameters and photosynthetic capacity of soybean plants, which can help to maintain optimum growth and development under changing light conditions. In addition, the dynamics of chlorophyll fluorescence parameters at $\mathrm{V}_{4}$ and $\mathrm{R}_{1}$ stages under different light treatments showed the consistent pattern with those of at $\mathrm{R}_{5}$ stage.

Table 2. Effect of different photosynthetically active radiations treatments on chlorophyll fluorescence characteristics (Fv/Fm; quantum yield, ФPSII; effective quantum yield of photosystem, qP; photochemical quenching, and ETR; electron transport rate) of soybean plants at $V_{4}$ (four trifoliate stage), $R_{1}$ (flower initiation stage), and $R_{5}$ (seed formation stage)

\begin{tabular}{|c|c|c|c|c|c|}
\hline \multirow[t]{2}{*}{ Stages } & \multirow[t]{2}{*}{ Treatments } & \multicolumn{4}{|c|}{ Chlorophyll Fluorescence Characteristics } \\
\hline & & ФPSII & $\mathrm{qP}$ & ETR & $\mathrm{FV} / \mathrm{FM}$ \\
\hline \multirow[t]{5}{*}{$\mathrm{V}_{4}$} & $\mathrm{~T}_{75}$ & $0.21 \mathrm{c}$ & $0.40 \mathrm{c}$ & $92.93 \mathrm{c}$ & $0.76 b$ \\
\hline & $\mathrm{T}_{50}$ & $0.22 b$ & $0.42 b$ & $97.61 b$ & $0.77 b$ \\
\hline & $\mathrm{T}_{25}$ & $0.24 \mathrm{a}$ & $0.43 b$ & $102.00 \mathrm{a}$ & $0.78 \mathrm{a}$ \\
\hline & $\mathrm{T}_{0}$ & $0.24 \mathrm{a}$ & $0.45 \mathrm{a}$ & $105.54 \mathrm{a}$ & $0.79 \mathrm{a}$ \\
\hline & LSD & 0.01 & 0.01 & 4.35 & 0.00 \\
\hline \multirow[t]{5}{*}{$\mathrm{R}_{1}$} & $\mathrm{~T}_{75}$ & $0.28 \mathrm{~d}$ & $0.60 \mathrm{c}$ & $122.26 \mathrm{~d}$ & $0.76 \mathrm{~d}$ \\
\hline & $\mathrm{T}_{50}$ & $0.30 \mathrm{c}$ & $0.62 b$ & $130.62 c$ & $0.78 \mathrm{c}$ \\
\hline & $\mathrm{T}_{25}$ & $0.32 b$ & $0.64 \mathrm{a}$ & $136.99 b$ & $0.79 b$ \\
\hline & $\mathrm{T}_{0}$ & $0.33 \mathrm{a}$ & $0.65 a$ & $143.08 \mathrm{a}$ & $0.80 \mathrm{a}$ \\
\hline & LSD & 0.01 & 0.01 & 5.40 & 0.00 \\
\hline \multirow[t]{5}{*}{$\mathrm{R}_{5}$} & $\mathrm{~T}_{75}$ & $0.31 \mathrm{~d}$ & $0.60 \mathrm{c}$ & $132.46 \mathrm{~d}$ & $0.77 \mathrm{~d}$ \\
\hline & $\mathrm{T}_{50}$ & $0.34 \mathrm{c}$ & $0.63 b$ & $148.47 \mathrm{c}$ & $0.78 \mathrm{c}$ \\
\hline & $\mathrm{T}_{25}$ & $0.37 b$ & $0.68 \mathrm{a}$ & $160.37 b$ & $0.80 \mathrm{~b}$ \\
\hline & $\mathrm{T}_{0}$ & $0.39 a$ & $0.69 a$ & $166.88 \mathrm{a}$ & $0.81 \mathrm{a}$ \\
\hline & LSD & 0.00 & 0.01 & 3.47 & 0.00 \\
\hline
\end{tabular}

$\mathrm{T}_{75}, \mathrm{~T}_{50}, \mathrm{~T}_{25}$, and $\mathrm{T}_{0}$ refer to $75 \%, 50 \%, 25 \%$, and $0 \%$ shade, respectively

\section{Carbon status, Rubisco Activity and Gene Expression}

To further study the impact of shade treatments on soybean growth, we measured the total soluble sugar and starch content of soybean root and shoot at the end of day. As expected, total soluble sugar and starch content were considerably increased with decreasing shade treatments (from $\mathrm{T}_{75}$ to $\mathrm{T}_{0}$ ) in both root and shoot. The highest total soluble sugar content $2.45 \mathrm{mg} \mathrm{g}^{-1}$ and $6.47 \mathrm{mg} \mathrm{g}^{-1}$, and starch content $0.37 \mathrm{mg} \mathrm{g}^{-1}$ and $0.69 \mathrm{mg} \mathrm{g}^{-1}$ were determined under treatment $\mathrm{T}_{0}$ followed by $\mathrm{T}_{25}$ (total soluble sugar content $1.95 \mathrm{mg} \mathrm{g}^{-1}$ and $6.25 \mathrm{mg} \mathrm{g}^{-1}$, and starch content $0.32 \mathrm{mg} \mathrm{g}^{-1}$ and $0.65 \mathrm{mg} \mathrm{g}^{-1}$ ) in root and shoot, whereas minimum total soluble sugar and starch content were measured in $\mathrm{T}_{75}$ treatment (Figure 3). In this experiment, a significant difference in Rubisco activity was measured in all treatments. Acceleration in the activity of Rubisco occurred in all treatments from $\mathrm{T}_{75}$ to $\mathrm{T}_{0}$, the amplitude of increase was higher under $\mathrm{T}_{0}$ than $\mathrm{T}_{75}$, $\mathrm{T}_{50}$, and $\mathrm{T}_{25}$ treatments. However, non-significant differences were observed between $\mathrm{T}_{25}$ and $\mathrm{T}_{0}$ treatment for Rubisco activity. Overall, the Rubisco activity of soybean plants under $\mathrm{T}_{25}$ was increased by $39 \%, 40 \%$ and $42 \%$ at $\mathrm{V}_{4}, \mathrm{R}_{1}$, and $\mathrm{R}_{5}$, respectively 
with respect to those under $\mathrm{T}_{75}$ treatment. These results indicate that the activity of Rubisco under $\mathrm{T}_{25}$ and $\mathrm{T}_{0}$ showed the similar trend and shade of $25 \%$ can be effective at the enzymatic activity of Rubisco. Homologues of soybean sucrose phosphate synthase (GmSPS1T1 and GmSPS2T2) and sucrose synthase (GmSS) were selected after blast against Arabidopsis to determine gene expression under different treatments. All three genes for sucrose phosphate synthase and sucrose synthase were up-regulated with increasing light at $\mathrm{V}_{4}$ stage. Relative to $\mathrm{T}_{75}$ treatment, the expression of GmSPS1 $1 T_{1}$ and GmSPS2T2 were increased by 0.34 and 0.42 folds in $\mathrm{T}_{25}$, respectively. While the expression of $G m S S$ was enhanced by 2.3 folds in treatment $\mathrm{T}_{25}$ than $\mathrm{T}_{75}$ Figure 4.

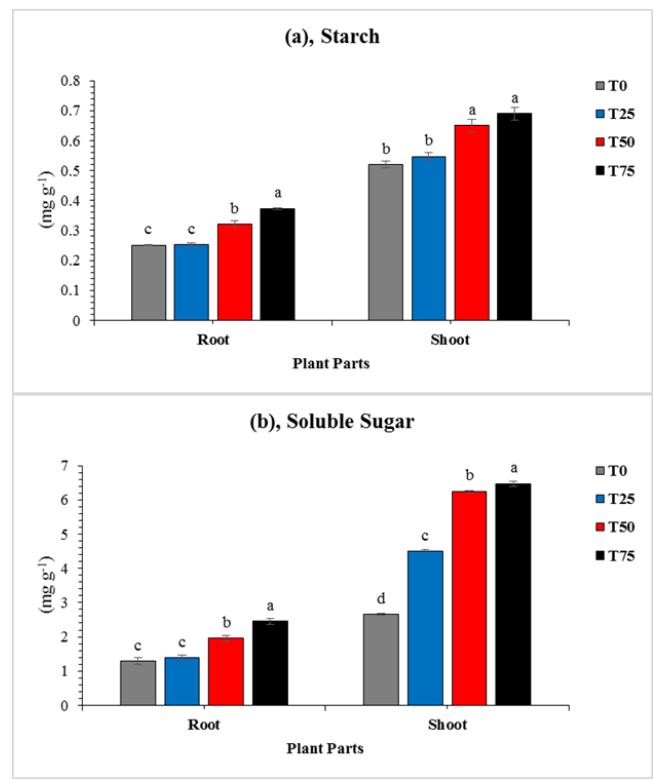

Figure 3. Changes in starch content (a) and soluble sugar content (b) of soybean leaves as affected by different photosynthetically active radiations treatments at $V_{4}$ (four trifoliate stage). $T_{75}, T_{50}, T_{25}$, and $T_{0}$ refer to $75 \%, 50 \%, 25 \%$, and $0 \%$ shade, respectively. Means are averaged over three replicates. Bars show \pm standard errors, $(n=3)$. Within a bar, different lowercase letters show a significant difference $(p \leq 0.05)$ between treatments

\section{Biomass Accumulation and Distribution}

Changing light conditions significantly affected the total biomass accumulation (TBA) $\left(\mathrm{g} \mathrm{plant}^{-1}\right)$ of soybean plants at various stages. In our study, the maximum TBA was 6.7, 22.4, and 35.5 under treatment $\mathrm{T}_{0}$, while minimum TBA 4.1, 8.5, and 19.4 was observed in $\mathrm{T}_{75}$ treatment at $\mathrm{V}_{4}, \mathrm{R}_{1}$, and $\mathrm{R}_{5}$, respectively (Table 3). However, soybean plants under $\mathrm{T}_{25}$ produced $86 \%, 76 \%$, and $85 \%$ of the $\mathrm{T}_{0}$ soybean biomass at $\mathrm{V}_{4}, \mathrm{R}_{1}$, and $\mathrm{R}_{5}$, respectively. Furthermore, we also measured the biomass distribution among root, stem, leaves, and pods at different growth stages of soybean in response to changing light conditions (Table 3). At $\mathrm{V}_{4}$ and $\mathrm{R}_{1}$ stages of soybean, the maximum biomass partitioning $\left(\mathrm{g} \mathrm{plant}^{-1}\right.$ ) was recorded in stem (3.8 and 13.4) followed by leaves $(2.7$ and 8.3) and root $(0.25$ and 0.65$)$ under $T_{0}$, while at $R_{5}$ biomass distribution pattern was changes and the highest biomass was found in leaves (16.2) followed by stem (14.9), pods (2.6) and root (1.7) in $\mathrm{T}_{0}$ treatment. Compared with $\mathrm{T}_{75}$ treatment, soybean plants under $\mathrm{T}_{25}$ and $\mathrm{T}_{0}$ treatments, respectively obtained $40 \%$ and $35 \%$ higher pod biomass at $\mathrm{R}_{5}$ stage. 


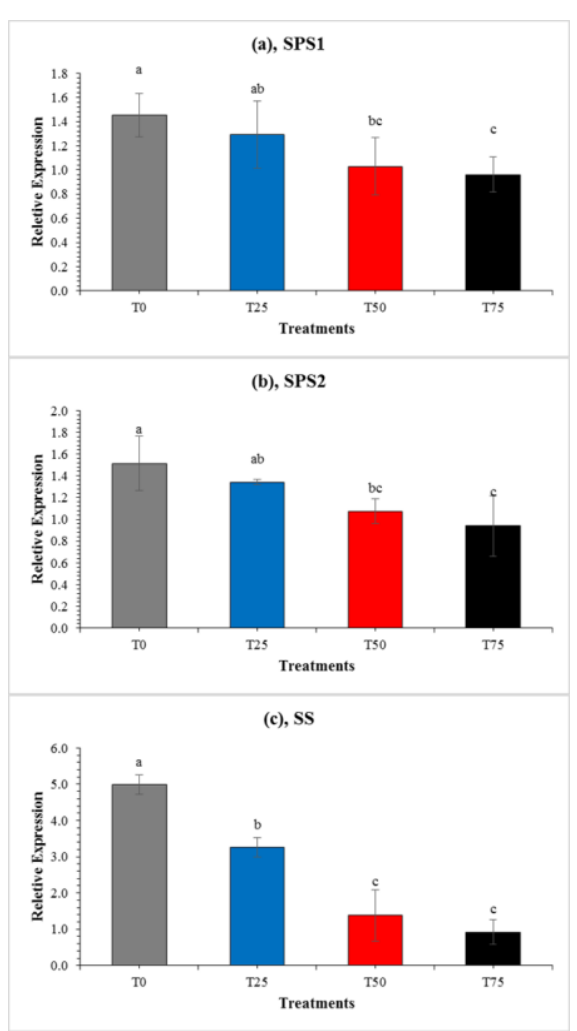

Figure 4. Relative expression of sucrose phosphate synthase Gmsps1, (a), Gmsps2, (b) and sucrose synthase Gmss (c) genes of soybean leaves as affected by different photosynthetically active radiations treatments at $V_{4}$ (four trifoliate stage). $T_{75}, T_{50}, T_{25}$, and $T_{0}$ refer to $75 \%, 50 \%$,

$25 \%$, and $0 \%$ shade, respectively. Means are averaged over three replicates. Bars show \pm standard errors, $(n=3)$. Within a bar, different lowercase letters show a significant difference $(p \leq 0.05)$ between treatments

Table 3. Effect of different photosynthetically active radiations treatments on biomass partitioning $\left(\mathrm{g} \mathrm{plant}^{-1}\right)$ among different plant parts and total biomass accumulation ( $\mathrm{g}$ plant $\left.{ }^{-1}\right)$ of soybean plants at $V_{4}$ (four trifoliate stage), $R_{1}$ (flower initiation stage), and $R_{5}$ (seed formation stage)

\begin{tabular}{|c|c|c|c|c|c|c|}
\hline \multirow[t]{2}{*}{ Stages } & \multirow[t]{2}{*}{ Treatments } & \multicolumn{4}{|c|}{ Biomass Partitioning } & \multirow{2}{*}{$\frac{\text { TBA }}{\left(\text { g plant }^{-1}\right)}$} \\
\hline & & Roots & Stem & Leaves & Pod & \\
\hline \multirow[t]{5}{*}{$\mathrm{V}_{4}$} & $\mathrm{~T}_{75}$ & $0.19 \mathrm{~d}$ & $2.43 \mathrm{~d}$ & $1.39 \mathrm{~d}$ & - & $4.01 \mathrm{~d}$ \\
\hline & $\mathrm{T}_{50}$ & $0.22 \mathrm{c}$ & $2.60 \mathrm{c}$ & $1.72 \mathrm{c}$ & - & $4.54 \mathrm{c}$ \\
\hline & $\mathrm{T}_{25}$ & $0.23 b$ & $3.38 b$ & $2.20 \mathrm{~b}$ & - & $5 . .81 b$ \\
\hline & $\mathrm{T}_{0}$ & $0.25 \mathrm{a}$ & $3.80 \mathrm{a}$ & $2.70 \mathrm{a}$ & - & $6.75 \mathrm{a}$ \\
\hline & LSD & 0.00 & 0.15 & 0.25 & - & 0.33 \\
\hline \multirow[t]{5}{*}{$\mathrm{R}_{1}$} & $\mathrm{~T}_{75}$ & $0.38 \mathrm{c}$ & $5.16 \mathrm{~d}$ & $2.95 \mathrm{~d}$ & - & $8.50 \mathrm{~d}$ \\
\hline & $\mathrm{T}_{50}$ & $0.41 \mathrm{c}$ & $6.43 c$ & $4.28 \mathrm{c}$ & - & $11.13 \mathrm{c}$ \\
\hline & $\mathrm{T}_{25}$ & $0.53 b$ & $10.46 b$ & $6.13 b$ & - & $17.13 b$ \\
\hline & $\mathrm{T}_{0}$ & $0.65 \mathrm{a}$ & $13.43 \mathrm{a}$ & $8.32 \mathrm{a}$ & - & $22.41 \mathrm{a}$ \\
\hline & LSD & 0.03 & 0.28 & 0.17 & - & 0.42 \\
\hline \multirow[t]{5}{*}{$\mathrm{R}_{5}$} & $\mathrm{~T}_{75}$ & $0.74 d$ & $7.73 \mathrm{~d}$ & $9.33 c$ & $1.59 \mathrm{~d}$ & $19.39 d$ \\
\hline & $\mathrm{T}_{50}$ & $0.91 \mathrm{c}$ & $9.49 \mathrm{c}$ & $11.27 b$ & $2.05 \mathrm{c}$ & $23.73 c$ \\
\hline & $\mathrm{T}_{25}$ & $1.31 \mathrm{~b}$ & $11.48 \mathrm{~b}$ & $15.04 \mathrm{a}$ & $2.45 b$ & $30.29 b$ \\
\hline & $\mathrm{T}_{0}$ & $1.68 \mathrm{a}$ & $14.92 \mathrm{a}$ & $16.23 \mathrm{a}$ & $2.65 \mathrm{a}$ & $35.49 \mathrm{a}$ \\
\hline & LSD & 0.02 & 0.75 & 1.38 & 0.12 & 1.58 \\
\hline
\end{tabular}

$\mathrm{T}_{75}, \mathrm{~T}_{50}, \mathrm{~T}_{25}$, and $\mathrm{T}_{0}$ refer to $75 \%, 50 \%, 25 \%$, and $0 \%$ shade, respectively 


\section{Yield and Yield Components}

In our study, there was a significant impact of different light treatments on seed yield of soybean plants Figure 5. The highest seed yield, $15.1 \mathrm{~g} \mathrm{plant}^{-1}$, was recorded in $\mathrm{T}_{0}$ treatment. Relative to $\mathrm{T}_{75}$, soybean plants under $\mathrm{T}_{25}$ and $\mathrm{T}_{0}$ produced the $22 \%$ and $31 \%$ higher seed yield. Yield parameters also varied among different light treatments. The effects of light treatments on pod number $\left(\right.$ plant $\left.^{-1}\right)$, seed number $\left(\right.$ plant $\left.^{-1}\right)$ and seed weight $(\mathrm{mg})$ were significant, and pod number and seed number under $\mathrm{T}_{0}$ treatment were found significantly higher than that in $\mathrm{T}_{75}, \mathrm{~T}_{50}$, and $\mathrm{T}_{25}$. Meanwhile, seed weight was found considerably heavier in $\mathrm{T}_{75}$ as compared to treatment $\mathrm{T}_{0}$. Overall, light treatment $\mathrm{T}_{25}$ and $\mathrm{T}_{0}$ increased the pod number and seed number by $37 \%$ and $44 \%$, and $38 \%$ and $45 \%$ as compared to treatment $\mathrm{T}_{75}$, respectively, while $\mathrm{T}_{75}$ treatment enhanced the seed weight of soybean seeds by $21 \%$ than $\mathrm{T}_{0}$ treatment Figure 5.

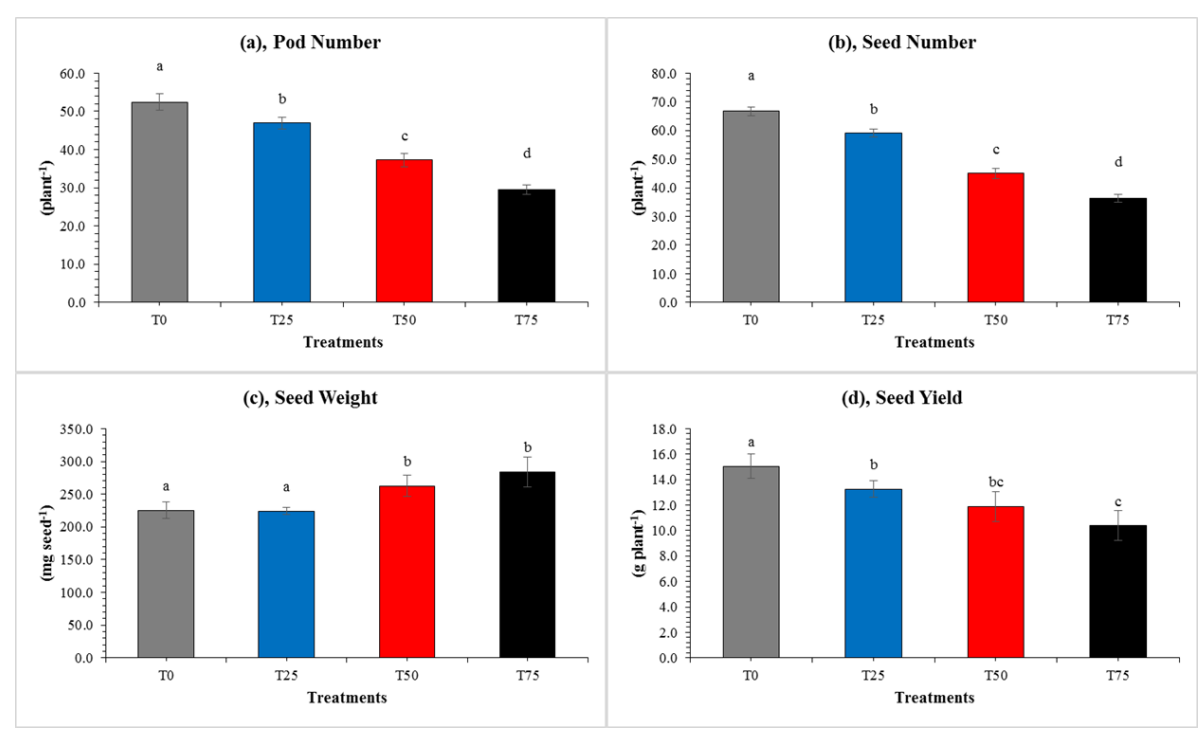

Figure 5. Changes in pod number (a), seed number (b), seed weight (c), and seed yield (d) of soybean plants as affected by different photosynthetically active radiations treatments at $V_{4}$ (four trifoliate stage). $T_{75}, T_{50}, T_{25}$, and $T_{0}$ refer to $75 \%, 50 \%, 25 \%$, and $0 \%$ shade, respectively. Means are averaged over three replicates. Bars show \pm standard errors, $(n=3)$. Within a bar, different lowercase letters show a significant difference $(p \leq 0.05)$ between treatments

\section{Discussion}

The plant morphology has certain manipulability, and corresponding adaptation mechanisms present in changing environmental conditions (Gong et al., 2015). Use of higher planting density is the effective method for enhancing seed yields (Liu et al., 2015a). However, this practice is typically obstructed by impair light conditions ( $\mathrm{Li}$ et al., 2014a). Numerous experiments have reported that shading conditions favor the upward growth of stem while reducing the stem breaking strength and stem diameter (Kurepin et al., 2007; Gommers et al., 2013; Yang et al., 2014). However, very few studies have Paidattention on the effect of changing shade treatments on soybean morphology to understand the threshold level of shade which will not affect the optimum soybean growth. In this study, a gradual decrease in shade (from $\mathrm{T}_{75}$ to $\mathrm{T}_{0}$ ) significantly increased the stem diameter and stem breaking strength by maintaining the 
optimum plant height of soybean plants (Figure 1). These findings showed that any variation in available light at soybean canopy directly affect the morphological characteristics of soybean plants and improved light availability positively improved the soybean growth by enhancing stem breaking strength which reduced the soybean lodging (Liu et al., 2016). Importantly, soybean plants under treatment $\mathrm{T}_{25}$ obtained superior morphological characters than $\mathrm{T}_{75}$ and $\mathrm{T}_{50}$, suggesting that under $25 \%$ of shade soybean plants can maintain their optimum growth. Sun-light stimulates the plant growth and development; by photosynthesis process, plants use sun-light to convert $\mathrm{H}_{2} \mathrm{O}$ and $\mathrm{CO}_{2}$ into carbohydrate, photosynthetic pigments (Chl a, $\mathrm{Chl} \mathrm{b}$, and $\mathrm{Chl} \mathrm{a+b}$ ) playan important role in changing the solar energy to chemical energy (Liang, 2000; Yuncong et al., 2007). In changing light conditions, the study of $\mathrm{Chl} \mathrm{a,} \mathrm{Chl} \mathrm{b,} \mathrm{and}$ $\mathrm{Chl} \mathrm{a}+\mathrm{b}$ helps as an indices for sun-light absorption (Fan et al., 2018). In past reports, researchers have confirmed that $\mathrm{Chl}$ contents significantly affected by changes in light availability and decrease with the reduction in light (Li et al., 2014a,b). Similarly,

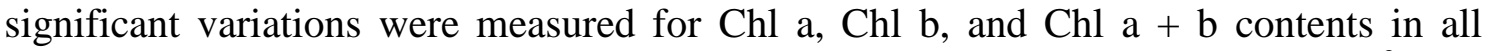
shade treatments, and chlorophyll contents were enhanced from 2.4 to $4.6 \mathrm{mg} \mathrm{cm}{ }^{3}$ with the decrease in shade from $\mathrm{T}_{75}$ to $\mathrm{T}_{0}$, respectively, our results are consistent with previously reported results (Wittmann et al., 2001; Fan et al., 2018). On the other hand, several scientists have claimed that $\mathrm{Chl} \mathrm{a}, \mathrm{Chl} \mathrm{b}$, and $\mathrm{Chl} \mathrm{a}+\mathrm{b}$ contents increase with the increase in shade, especially $\mathrm{Chl} b$ contents ( $\mathrm{Li}$ et al., 2014a).

In addition to the impacts of changing light conditions on morphology and chlorophyll contents our results showed that deleterious effects of increase shade eliminated by adequate light availability (treatment $\mathrm{T}_{25}$ and $\mathrm{T}_{0}$ ). There are many causes why soybean plants under high shade conditions produced less carbohydrate. For instance, researchers have concluded that assimilate demands of soybean plants increased while photosynthetic rate decreased under increased shade conditions ( $\mathrm{Su}$ et al., 2014; Yang et al., 2017). In this experiment, optimum light $\left(\mathrm{T}_{25}\right.$ and $\left.\mathrm{T}_{0}\right)$ at soybean canopy led to increase the photosynthetic rate and transpiration rate while stomatal conductance and intercellular carbon dioxide levels were decreased. Therefore, this showed that the enhanced photosynthetic characteristics increased the carbon gain and improved the soybean growth (Liao et al., 2005). Moreover, these findings indicating that the increased photosynthetic rate under $\mathrm{T}_{25}$ and $\mathrm{T}_{0}$ treatments may be associated with the higher chlorophyll contents (i.e. higher $\mathrm{Chl} \mathrm{a}, \mathrm{Chl} \mathrm{b}$, and $\mathrm{Chl} \mathrm{a}+\mathrm{b}$ contents at $\mathrm{V}_{4}, \mathrm{R}_{1}$, and $\mathrm{R}_{5}$, (Figure 2) of soybean leaves (Feng et al., 2018). Improved photosynthetic capacity is always accompanied with high quantity of electrons passing through PSII (Yao et al., 2017). Chl fluorescence parameters are one of the major factors in regulation of photosynthesis and crop responses to environmental conditions because of its sensitivity and convenience (Dai et al., 2009). In addition, total soluble sugar and starch content are the direct measure of high photosynthetic rate (Iqbal et al., 2018a). Crops translocate carbohydrate from source leaves to different plant parts that decides the plants fitness under changing environments (Amiard et al., 2005). Numerous previous experiments confirmed the role of light intensity for the production of total soluble sugar and starch content in plants (Preiss, 1982; Michalska et al., 2009). Similarly, we found that the total soluble sugar and starch content were considerably improved by $33 \%$ and $144 \%$ in $\mathrm{T}_{0}$ than $\mathrm{T}_{75}$. These results were in agreement with past reports (Pilkington et al., 2015). Previous experiments have confirmed that heavy shade results in reduce photosynthesis due to the decrease in qP, PSII and ETR (Huang et al., 2011; Yao et al., 2017; Feng et al., 2018). In this experiment, similar results were 
obtained, however, improved $\mathrm{Chl}$ fluorescence characteristics were measured under $\mathrm{T}_{25}$ and $\mathrm{T}_{0}$ treatments. These results reveals that optimum light intensity (treatment $\mathrm{T}_{25}$ and $\mathrm{T}_{0}$ ) improves the efficiency of PSII and ETR that could enhance the photosynthetic capacity of soybean plants by improving the energy transport from PSII to PSI, our results are consistent with previously reported results (Yang et al., 2018a). The loss of rubisco activity was recognized to be very early and fast response of crop plants to shade stress (Servaites et al., 1986). While, at $\mathrm{R}_{5}$, in current research the activity of rubisco was significantly accelerated in $\mathrm{T}_{0}\left(0.38 \mu \mathrm{mol} \mathrm{CO} \mathrm{g}^{-1} \mathrm{FW} \mathrm{min}{ }^{-1}\right)$ and $\mathrm{T}_{25}$ $\left(0.36 \mu \mathrm{mol} \mathrm{CO} \mathrm{C}^{-1} \mathrm{FW} \mathrm{min}^{-1}\right)$ as compared to $\mathrm{T}_{75}\left(0.19 \mu \mathrm{mol} \mathrm{CO}_{2} \mathrm{~g}^{-1} \mathrm{FW} \mathrm{min}{ }^{-1}\right)$ (Table 1), our findings are consistent with past reports (Carmo-Silva and Salvucci, 2013). This higher rubisco activity under decreased shade treatments $\left(T_{25}\right.$ and $T_{0}$ ) exhibited that the higher photosynthetic rate of soybean plants directly correlated with rubisco activity under changing environments (Zhang et al., 2002).

This study provides the important data on biomass accumulation in soybean plants in different shade treatments (Table 3). Increased photosynthetic rate is one of the main factors for plant biomass production (Raza et al., 2018b). Previously, researchers have found that biomass accumulation is directly associated with the availability of light intensity (Kiniry et al., 2004) and reductions in light decreased the biomass production (Maddonni and Otegui, 2004). Our findings proposed that an adequate light availability $\left(\mathrm{T}_{25}\right.$ and $\left.\mathrm{T}_{0}\right)$ at soybean canopy can increase biomass accumulation by capturing and utilizing sun-light for their biochemical and physiological processes which in turn increased availability of carbohydrates for seed formation and this finding was similar to previous result (Liu et al., 2015b). Moreover, the accelerated dry matter production in soybean may be related to the utilization of major nutrients (Raza et al., 2018a) as the nutrient uptake ability of crops increased with improve light conditions (Yang et al., 2017). Additionally, we also measured the biomass partitioning in leaves, stem, pods, and seed of soybean plants in response to different shade treatments (Table 3). The dry matter partitioning changed considerably at $\mathrm{V}_{4}, \mathrm{R}_{1}$, and $\mathrm{R}_{5}$ in soybean in all treatments. At $V_{4}$ and $R_{1}$, when reproductive parts were the weak sink the highest allocation of plant-biomass was determined in stem followed by leaves (Jasdanwala and Khan, 1988; Srinivasan et al., 2017). After that, at $\mathrm{R}_{1}$ and $\mathrm{R}_{5}$, the plant-biomass distribution changed and the most of plant-biomass assimilated to the leaves and pods in all treatments (Couch et al., 2017). Similar to our findings researchers have reported that optimum light intensity increased the assimilation of plant-biomass to economic parts, while decreased the dry matter partitioning to vegetative organs (Jasdanwala and Khan, 1988). Nevertheless, severe shading conditions $\left(\mathrm{T}_{75}\right.$ and $\left.\mathrm{T}_{50}\right)$ increased the retention of plantbiomass in stems (Wu et al., 2017) which did not promote the seed formation process and decreased the seed yield (Figure 5). These findings of plant-biomass partitioning demonstrated that accelerated translocation of photo-assimilates from the stem for pod formation occurred in soybean plants of treatments $T_{25}$ and $T_{0}$, while severe shading conditions was not favorable to plant-biomass partitioning to pod.

Previously, it has been found that severe shading conditions significantly decreased the soybean yield and yield components (Wu et al., 2016; Iqbal et al., 2018b). Similarly, in our study, treatment $\mathrm{T}_{75}$ (severe shading) had significant negative effect on seed yield and yield related parameters, and minimum pod number $\left(29.9\right.$ plant $\left.^{-1}\right)$ and seed number (36.4 plant $\left.^{-1}\right)$, and seed yield (10.4 g plant $^{-1}$ ) of soybean were noticed in $\mathrm{T}_{75}$ treatments. This is might be due to the lower photosynthetic rate and biomass accumulation, similar to our results in another study of relay-intercropping scientist has reported that soybean 
seed yield of soybean plants significantly decreased in severe shading conditions as compared to normal conditions (Yang et al., 2017). Moreover, light enrichment treatments significantly increased the pod number and seed yield of soybean. Hence, pod number (52.4 and 46.9 plant $^{-1}$ ) and seed number (66.7 and 59.1 plant $^{-1}$ ) of soybean plants might be improved in adequate light $\left(\mathrm{T}_{25}\right.$ and $\mathrm{T}_{0}$, respectively), these results implied that optimum light availability at soybean canopy can significantly improve the morphological parameters, photosynthetic and chlorophyll florescence characteristics which in turn considerably increased the seed yield of soybean plants by increasing the pod number and seed number.

\section{Conclusion}

The significant impacts of shade treatments on soybean have been studied previously, but rarely researchers have investigated the effects of different shade treatments on soybean plants to understand the threshold level of shade for the better growth and development. In this experiment, we showed that by selecting the shade tolerant variety soybean plants can cope shade up to $25 \%\left(\mathrm{~T}_{25}\right)$. Increased shade $\left(\mathrm{T}_{75}\right)$ considerably impaired the morphological characteristics (Figure 1), enzymatic activity of key enzyme (Rubisco) by down-regulating the important sucrose-synthase-genes (Figure 4). In addition, as compared to $\mathrm{T}_{75}$, treatment $\mathrm{T}_{0}$ and $\mathrm{T}_{25}$ significantly improved the photosynthetic and chlorophyll florescence characteristics of soybean plants especially quantum yield of PSII which in turn considerably increased the seed yield and yieldcomponents (Figure 5). Overall, these results implied that agronomist should have to develop an appropriate intercropping planting pattern where the maximum shade density ranges from 20 to $30 \%$ to obtain higher seed yield of soybean crop under intercropping-system. This could be achieved by developing the narrow-wide row planting pattern in which maize plants can grow under narrow rows and soybean plants can grow in wide rows by maintaining the appropriate distance in which soybean plants can receive enough light for their optimum growth. In addition, developing the long term and environment friendly agronomic approaches to improve the seedling growth of soybean under intercropping systems by reducing the shade density in maize soybean intercropping system is an important direction for future research.

Conflict of interests. The authors have declared no conflict of interests.

\section{REFERENCES}

[1] Amiard, V., Mueh, K. E., Demmig, A. B., Ebbert, V., Turgeon, R., Adams, W. W. (2005): Anatomical and photosynthetic acclimation to the light environment in species with differing mechanisms of phloem loading. - PNAS 102: 12968-12973.

[2] Carmo-Silva, A. E., Salvucci, M. E. (2013): The regulatory properties of rubisco activase differ among species and affect photosynthetic induction during light transitions. - Plant physiol. 112.213348.

[3] Couch, A., Jani, A., Mulvaney, M., Hochmuth, G., Bennett, J., Gloaguen, R., Langham, R., Rowland, D. (2017): Nitrogen accumulation, partitioning, and remobilization by diverse sesame cultivars in the humid southeastern USA. - Field Crops Res. 203: 55-64.

[4] Cross, J. M., von Korff, M., Altmann, T., Bartzetko, L., Sulpice, R., Gibon, Y., Palacios, N., Stitt, M. (2006): Variation of enzyme activities and metabolite levels in 24 
arabidopsis accessions growing in carbon-limited conditions. - Plant Physiol. 142: 15741588.

[5] Dai, Y., Shen, Z., Liu, Y., Wang, L., Hannaway, D., Lu, H. (2009): Effects of shade treatments on the photosynthetic capacity, chlorophyll fluorescence, and chlorophyll content of tetrastigma hemsleyanum diels et gilg. - Environ. Exp. Bot. 65: 177-182.

[6] Delfine, S., Alvino, A., Villani, M. C., Loreto, F. (1999): Restrictions to carbon dioxide conductance and photosynthesis in spinach leaves recovering from salt stress. - Plant Physiol. 119: 1101-1106.

[7] Evans, J. R., Seemann, J. R. (1989): The allocation of protein nitrogen in the photosynthetic apparatus: Costs, consequences, and control. - Photosynthesis: 183-205.

[8] Fan, Y., Chen, J., Cheng, Y., Raza, M. A., Wu, X., Wang, Z., Liu, Q., Wang, R., Wang, X., Yong, T. (2018): Effect of shading and light recovery on the growth, leaf structure, and photosynthetic performance of soybean in a maize-soybean relay-strip intercropping system. - PloS one 13: e0198159.

[9] Feng, L. Y., Raza, M. A., Li, Z. C., Chen, Y., Khalid, M. H. B., Du, J., Liu, W., Wu, X., Song, C., Yu, L. (2018): The influence of light intensity and leaf movement on photosynthesis characteristics and carbon balance of soybean. - Fron. Plant Sci. 9: 1952.

[10] Gommers, C. M., Visser, E. J., St Onge, K. R., Voesenek, L. A., Pierik, R. (2013): Shade tolerance: When growing tall is not an option. - Trends Plant Sci. 18: 65-71.

[11] Gong, W., Jiang, C., Wu, Y., Chen, H., Liu, W., Yang, W. (2015): Tolerance vs. Avoidance: Two strategies of soybean (glycine max) seedlings in response to shade in intercropping. - Photosynthetica 53: 259-268.

[12] Huang, D., Wu, L., Chen, J., Dong, L. (2011): Morphological plasticity, photosynthesis and chlorophyll fluorescence of athyrium pachyphlebium at different shade levels. Photosynthetica 49: 611-618.

[13] Iqbal, N., Hussain, S., Zhang, X. W., Yang, C. Q., Raza, M., Deng, J. C., Ahmad, S., Ashgar, M., Zhang, J., Yang, W. (2018a): Imbalance water deficit improves the seed yield and quality of soybean. - Agronomy 8: 168.

[14] Iqbal, N., Hussain, S., Ahmed, Z., Yang, F., Wang, X., Liu, W., Yong, T., Du, J., Shu, K., Yang, W. (2018b): Comparative analysis of maize-soybean strip intercropping systems. A review. - Plant Prod. Sci. doi.org/10.1080/1343943X.2018.1541137.

[15] Jasdanwala, R., Khan, A. (1988): 14c-labelled assimilate distribution in flowering maize plants. - J. Agron. Crop Sci. 161: 249-255.

[16] Kao, W. Y., Tsai, T. T., Shih, C. N. (2003): Photosynthetic gas exchange and chlorophyll a fluorescence of three wild soybean species in response to nacl treatments. Photosynthetica 41: 415-419.

[17] Kiniry, J. R., Bean, B., Xie, Y., Chen, P. Y. (2004): Maize yield potential: Critical processes and simulation modeling in a high-yielding environment. - Agric. Sys. 82: 4556.

[18] Kong, D. X., Li, Y. Q., Wang, M. L., Bai, M., Zou, R., Tang, H., Wu, H. (2016): Effects of light intensity on leaf photosynthetic characteristics, chloroplast structure, and alkaloid content of mahonia bodinieri (gagnep.) laferr. - Act. Phy. Plant. 38: 120.

[19] Kurepin, L. V., Emery, R. N., Pharis, R. P., Reid, D. M. (2007): The interaction of light quality and irradiance with gibberellins, cytokinins and auxin in regulating growth of helianthus annuus hypocotyls. - Plant Cell Environ. 30: 147-155.

[20] Li, T., Liu, L. N., Jiang, C. D., Liu, Y. J., Shi, L. (2014a): Effects of mutual shading on the regulation of photosynthesis in field-grown sorghum. - J. Photochem. Photobiol. B. 137: 31-38.

[21] Li, R., Wen, T., Tang, Y., Sun, X., Xia, C. (2014b): Effect of shading on photosynthetic and chlorophyll fluorescence characteristics of soybean. - Acta Pratacult. Sin. 23: 198206.

[22] Liang, Z. (2000): Studies on variation and difference of characters of stem and leaf between shade-enduring and shade-non-enduring soybeans. - Soybean Sci. 19: 35-41. 
[23] Liao, J. X., Ge, Y., Huang, C. C., Zhang, J., Liu, Q. X., Chang, J. (2005): Effects of irradiance on photosynthetic characteristics and growth of mosla chinensis and $\mathrm{m}$. Scabra. - Photosynthetica 43: 111-115.

[24] Lichtenthaler, H., Buschmann, C., Döll, M., Fietz, H. J., Bach, T., Kozel, U., Meier, D., Rahmsdorf, U. (1981): Photosynthetic activity, chloroplast ultrastructure, and leaf characteristics of high-light and low-light plants and of sun and shade leaves. Photosynth. Res 2: 115-141.

[25] Liu, T., Gu, L., Dong, S., Zhang, J., Liu, P., Zhao, B. (2015a): Optimum leaf removal increases canopy apparent photosynthesis, 13c-photosynthate distribution and grain yield of maize crops grown at high density. - Field Crops Res. 170: 32-39.

[26] Liu, W., Zou, J., Zhang, J., Yang, F., Wan, Y., Yang, W. (2015b): Evaluation of soybean (glycine max) stem vining in maize-soybean relay strip intercropping system. - Plant Prod. Sci. 18: 69-75.

[27] Liu, W., Deng, Y., Hussain, S., Zou, J., Yuan, J., Luo, L., Yang, C., Yuan, X., Yang, W. (2016): Relationship between cellulose accumulation and lodging resistance in the stem of relay intercropped soybean [glycine max (1.) merr.]. - Field Crops Res. 196: 261-267.

[28] Liu, X., Rahman, T., Song, C., Yang, F., Su, B., Cui, L., Bu, W., Yang, W. (2018): Relationships among light distribution, radiation use efficiency and land equivalent ratio in maize-soybean strip intercropping. - Field Crops Res. 224: 91-101.

[29] Maddonni, G., Otegui, M. (2004): Intra-specific competition in maize: Early establishment of hierarchies among plants affects final kernel set. - Field Crops Res. 85: $1-13$.

[30] Mauser, H., King, W. A., Gready, J. E., Andrews, T. J. (2001): Co2 fixation by rubisco: Computational dissection of the key steps of carboxylation, hydration, and $\mathrm{c}-\mathrm{c}$ bond cleavage. - J. Am. Chem. Soc. 123: 10821-10829.

[31] Michalska, J., Zauber, H., Buchanan, B. B., Cejudo, F. J., Geigenberger, P. (2009): Ntrc links built-in thioredoxin to light and sucrose in regulating starch synthesis in chloroplasts and amyloplasts. - PNAS 106: 9908-9913.

[32] Pan, Y., Lu, Z., Lu, J., Li, X., Cong, R., Ren, T. (2017): Effects of low sink demand on leaf photosynthesis under potassium deficiency. - Plant Physiol Biochem. 113: 110-121.

[33] Pilkington, P. D., Milne, L. C., Cairns, K. E., Lewis, J., Whelan, T. A. (2015): Modifiable partner factors associated with perinatal depression and anxiety: A systematic review and meta-analysis. - J. Aff. Dis. 178: 165-180.

[34] Preiss, J. (1982): Biosynthesis of starch and its regulation. - Plant Carb.: 397-417.

[35] Rahman, T., Liu, X., Hussain, S., Ahmed, S., Chen, G., Yang, F., Chen, L., Du, J., Liu, W., Yang, W. (2017): Water use efficiency and evapotranspiration in maize-soybean relay strip intercrop systems as affected by planting geometries. - PloS one 12: e0178332.

[36] Ranjbarfordoei, A., Samson, R., Van Damme, P. (2006): Chlorophyll fluorescence performance of sweet almond [prunus dulcis (miller) d. Webb] in response to salinity stress induced by nacl. - Photosynthetica 44: 513-522.

[37] Rascher, U., Liebig, M., Lüttge, U. (2000): Evaluation of instant light-response curves of chlorophyll fluorescence parameters obtained with a portable chlorophyll fluorometer on site in the field. - Plant Cell Environ. 23: 1397-1405.

[38] Raza, M. A., Feng, L. Y., Manaf, A., Wasaya, A., Ansar, M., Hussain, A., Khalid, M. H. B., Iqbal, N., Xi, Z. J., Chen, Y. K. (2018a): Sulphur application increases seed yield and oil content in sesame seeds under rainfed conditions. - Field Crops Res. 218: 51-58.

[39] Raza, M., Feng, L., Iqbal, N., Manaf, A., Khalid, M., Wasaya, A., Ansar, M., Billah, M., Yang, F., Yang, W. (2018b): Effect of sulphur application on photosynthesis and biomass accumulation of sesame varieties under rainfed conditions. - Agronomy 8: 149.

[40] Redondo-Gómez, S., Mateos-Naranjo, E., Davy, A. J., Fernández-Muñoz, F., Castellanos, E. M., Luque, T., Figueroa, M. E. (2007): Growth and photosynthetic responses to salinity of the salt-marsh shrub atriplex portulacoides. - Ann. Bot. 100: 555-563. 
[41] Schreiber, U., Bilger, W., Neubauer, C. (1995): Chlorophyll fluorescence as a nonintrusive indicator for rapid assessment of in vivo photosynthesis. - Ecophysiol. Photosynth.: 49-70.

[42] Seemann, J. R. (1989): Light adaptation/acclimation of photosynthesis and the regulation of ribulose-1, 5-bisphosphate carboxylase activity in sun and shade plants. - Plant Physiol. 91: 379-386.

[43] Seemann, J. R., Sharkey, T. D. (1986): Salinity and nitrogen effects on photosynthesis, ribulose-1, 5-bisphosphate carboxylase and metabolite pool sizes in phaseolus vulgaris 1. - Plant Physiol. 82: 555-560.

[44] Servaites, J. C., Parry, M. A., Gutteridge, S., Keys, A. J. (1986): Species variation in the predawn inhibition of ribulose-1, 5-bisphosphate carboxylase/oxygenase. - Plant Physiol. 82: 1161-1163.

[45] Shao, Q., Wang, H., Guo, H., Zhou, A., Huang, Y., Sun, Y., Li, M. (2014): Effects of shade treatments on photosynthetic characteristics, chloroplast ultrastructure, and physiology of anoectochilus roxburghii. - PloS one 9: e85996.

[46] Srinivasan, V., Kumar, P., Long, S. P. (2017): Decreasing, not increasing, leaf area will raise crop yields under global atmospheric change. - Global change bio. 23: 1626-1635.

[47] Stępień, P., Kłbus, G. (2006): Water relations and photosynthesis in cucumis sativus 1. Leaves under salt stress. - Biol. Plantarum 50: 610.

[48] Su, B., Song, Y., Song, C., Cui, L., Yong, T., Yang, W. (2014): Growth and photosynthetic responses of soybean seedlings to maize shading in relay intercropping system in southwest china. - Photosynthetica 52: 332-340.

[49] Wittmann, C., Aschan, G., Pfanz, H. (2001): Leaf and twig photosynthesis of young beech (fagus sylvatica) and aspen (populus tremula) trees grown under different light regime. - Basic Appl. Ecol. 2: 145-154.

[50] Wolff, X. Y., Coltman, R. R. (1990): Productivity under shade in hawaii of five crops grown as vegetables in the tropics. - J. Am. Soc. Hortic. Sci. 115: 175-181.

[51] Wu, Y., Gong, W., Yang, F., Wang, X., Yong, T., Yang, W. (2016): Responses to shade and subsequent recovery of soya bean in maize-soya bean relay strip intercropping. Plant Prod. Sci. 19: 206-214.

[52] Wu, Y., Gong, W., Yang, W. (2017): Shade inhibits leaf size by controlling cell proliferation and enlargement in soybean. - Sci. rep. 7: 9259.

[53] Wu, Y., Gong, W., Wang, Y., Yong, T., Yang, F., Liu, W., Wu, X., Du, J., Shu, K., Liu, J. (2018): Leaf area and photosynthesis of newly emerged trifoliolate leaves are regulated by mature leaves in soybean. - J. plant res. 131(4): 671-680.

[54] Yang, F., Huang, S., Gao, R., Liu, W., Yong, T., Wang, X., Wu, X., Yang, W. (2014): Growth of soybean seedlings in relay strip intercropping systems in relation to light quantity and red: Far-red ratio. - Field Crops Res. 155: 245-253.

[55] Yang, F., Lou, Y., Liao, D., Gao, R., Yong, T., Wang, X., Liu, W., Yang, W. (2015): Effects of row spacing on crop biomass, root morphology and yield in maize-soybean relay strip intercropping system. - Acta Agron. Sin 41: 642-650.

[56] Yang, F., Liao, D., Wu, X., Gao, R., Fan, Y., Raza, M. A., Wang, X., Yong, T., Liu, W., Liu, J. (2017): Effect of aboveground and belowground interactions on the intercrop yields in maize-soybean relay intercropping systems. - Field Crops Res. 203: 16-23.

[57] Yang, F., Feng, L., Liu, Q., Wu, X., Fan, Y., Raza, M. A., Cheng, Y., Chen, J., Wang, X., Yong, T. (2018a): Effect of interactions between light intensity and red-to-far-red ratio on the photosynthesis of soybean leaves under shade condition. - Environ Exp Bot 150: 7987.

[58] Yang, F., Fan, Y., Wu, X., Cheng, Y., Liu, Q., Feng, L., Chen, J., Wang, Z., Wang, X., Yong, T. (2018b): Auxin-to-gibberellin ratio as a signal for light intensity and quality in regulating soybean growth and matter partitioning. - Fron. Plant Sci. 9: 56. 
[59] Yao, X., Li, C., Li, S., Zhu, Q., Zhang, H., Wang, H., Yu, C., Martin, S. K. S., Xie, F. (2017): Effect of shade on leaf photosynthetic capacity, light-intercepting, electron transfer and energy distribution of soybeans. - Plant Growth Regul. 83: 409-416.

[60] Yuncong, Y., Shaohui, W., Yun, K. (2007): Characteristics of photosynthesis machinism in different peach species under low light intensity. - Sci Agric Sinica.

[61] Zhang, N., Kallis, R. P., Ewy, R. G., Portis, A. R. (2002): Light modulation of rubisco in arabidopsis requires a capacity for redox regulation of the larger rubisco activase isoform. - PNAS 99: 3330-3334.

[62] Zuber, M., Kang, M. (1978): Corn lodging slowed by sturdier stalks. - Crops and Soils 30(5):1-32. 